\title{
Thoracolumbar burst fracture with complete paraplegia: rationale for second-stage anterior decompression and fusion regarding functional outcome
}

\author{
Mukund M. Prabhakar · Bhagwat Singh Rao • \\ Lilam Patel
}

Received: 24 September 2008/Accepted: 19 April 2009/Published online: 26 May 2009

(C) Springer-Verlag 2009

\begin{abstract}
Background Appropriate management of thoracolumbar injury with complete paraplegia remains controversial. Purpose of present study is to study whether advantages are worth the morbidity associated with staged anterior decompression in these patients.

Materials and methods Forty patients (90\% male) with fracture of T12 (32 cases) and L1 (8 cases) with complete paraplegia underwent transpedicular fixation. Average age of patients was 42 years (range 13-57 years). Most common fracture pattern was type A3.1 (55\%). Rational staged anterior decompression was done in 20 cases. One group received transpedicular fixation $(n=20)$ and another fixation and staged decompression $(n=20)$. Average followup was 2.5 years.

Results Mean functional independence measurement (FIM) score was 98 in fixation group and 112 in decompression group; mean neurological recovery as measured by American Spinal Injury Association (ASIA) grade was 1.3 and 1.75, respectively. Incidence of postoperative
\end{abstract}

Statement regarding ethical standards: this study was performed in accordance with the ethical standards laid down in the 1964 Declaration of Helsinki and all persons gave their informed consent prior to inclusion in the study.

M. M. Prabhakar · L. Patel

Paraplegia Hospital, Civil Hospital, Ahmedabad, Gujarat, India

M. M. Prabhakar · L. Patel

Department of Orthopaedics, B.J. Medical College,

Ahmedabad, Gujarat, India

B. S. Rao $(\bowtie)$

Marble City Hospital, Kishangarh, Ajmer, Rajasthan, India

e-mail: drbhagwatsinghrao@yahoo.co.in complications was $20 \%$ and $60 \%$, respectively. Sphincter control did not recover in either group.

Conclusions Rehabilitation is better after staged anterior decompression and fusion in burst fracture of thoracolumbar junction with complete paraplegia.

Keywords Thoracolumbar junction .

Complete paraplegia - Pedicle screw · Decompression ·

Rehabilitation

\section{Introduction}

Biomechanically, thoracolumbar junction is susceptible to injury and is the most commonly injured portion of the spine $[1,2]$. Other organ system injury is encountered in up to $50 \%$ of thoracolumbar trauma patients [3-7]. Once one spine injury is diagnosed, it is especially important to examine the rest of the spine since noncontiguous injuries can be present $15 \%$ of the time [8].

Initial radiographic assessment includes anteroposterior (AP) and lateral spine films. Plain radiographs are not accurate in determining involvement of the posterior wall of the vertebral body [9]. Magnetic resonance imaging (MRI) is useful in evaluating those patients with neurological injury that cannot be accounted for by osseous disruption on plain radiographs and computed tomography (CT) scan. MRI can reveal injury to the spinal cord and ligaments, annulus fibrosis, disc herniations, and epidural hematomas [10-14].

One of the earliest classifications of spinal fractures was by Watson Jones in 1931, based primarily on diagnosis and treatment of flexion injuries [15]. One of the most popular classification systems is based on the "three-column" theory proposed by Denis in 1983 as an extension of the 
biomechanical work of Nagel $[16,17]$. Later on, loadsharing classification was proposed by McCormack [18] based on degree of comminution, apposition of fragments, and degree of deformity. The most useful classification of thoracolumbar injuries is the association for osteosynthesis/ association for the study of internal fixation (AO-ASIF) classification proposed by Magerl [19] based on pathomorphological characteristics of injuries. Three main categories with a common injury pattern were formed: type A-vertebral body compression (compression force), type $\mathrm{B}$ - anterior and posterior element injury with distraction (tensile force), and type $\mathrm{C}$-anterior and posterior element injury with rotation (axial torque). Further subclassification is primarily based on AO 3-3-3 grid.

Nonoperative treatment is indicated for stable injuries without the potential for progressive deformity or neurological injury. The most devastating complication of nonoperative treatment is development of neurological deterioration. Denis [20] noted that 6 of 29 nonoperatively treated burst fractures developed neurological deficit. On the other hand, Reid [21] and Cantor [22] noted no neurological worsening in their nonoperatively treated patients with burst fractures. Gertzbein demonstrated in a large study that kyphotic deformity greater than $30^{\circ}$ correlated with increased back pain [23]. In neurologically intact patients, nonoperative treatment is generally recommended [24]. The American Spinal Injury Association (ASIA) scoring system can assist in documenting, monitoring, and treating neurological injuries [25]. The use of methylprednisolone in the immediate postinjury phase has been shown to improve outcomes in the National Acute Spinal Cord Injury Study (NASCIS) [26], but this improvement has not been substantiated in their studies and its role remains controversial. Surgery is typically employed in patients with unstable injuries and significant neurological deficits. Laminectomy alone is not recommended for decompression of spinal column injuries in that it can further destabilize the spine [27].

Early reports of decompression and stabilization in patients with neurological deficit and thoracolumbar fracture demonstrated improvement that was equal to that of nonoperative results in the literature [28-34]. With the advent of newer instrumentation techniques and aggressive direct anterior decompression, the degree of neurological recovery appears more favorable than earlier reports [35-41]. Vertebroplasty and kyphoplasty are two techniques that show good potential in terms of decreasing pain and improving function in osteoporotic low-energy compression and burst fractures. Early reports demonstrate these techniques to be highly effective with good pain relief and relatively few complications [42-46]. Primary goals in thoracolumbar trauma patients are preservation of remaining spinal cord function, restoration of spinal alignment, achievement of pain-free fracture site, maximum neurological recovery, and early rehabilitation. This can be achieved by optimizing neural decompression while providing stable internal fixation over the least number of spinal segments [47]. The pedicle screw rod systems, by virtue of direct fixation through middle and anterior columns, are able to reduce fractures of these columns by ligamentotaxis [48-52]. Transpedicular screw rod construct is currently the standard in segmental fixation of thoracolumbar spine [53-55]. Posterior surgery with pedicle screw constructs over a short segment stabilizes the fracture and allows early mobilization, much as nonoperative regimes do. Recent prospective randomized studies comparing these two treatment options suggest there is no clinical advantage of surgery over nonoperative care $[56,57]$.

Surgery corrects deformity but modest recurrence is common, even with attempts to perform transpedicular bone grafting, as the anterior column remains deficient [58].

Anterior decompression will be more effective for anterior neural compression such as occurs in a burst fracture. Anterior decompression has been shown to increase axoplasmic flow, decrease ischemia, and lead to improvement of neurological function. The disadvantage of posterior approaches to achieve anterior decompression include the need to resect major portions of the neural arch (often uninjured) to obtain access to the middle column. Finally, it is difficult to reconstruct the anterior and middle columns after a posterior approach has been used to decompress a burst fracture, and there is significant incidence of construct failure [59].

The aim of this study is to weigh up the morbidity associated with anterior decompression with the ultimate functional outcome.

\section{Materials and methods}

Study followed ethical standards and was approved by institutional review board. Informed consent was obtained from all patients. Forty patients of posttraumatic instability of thoracolumbar transition with clinical signs of complete paraplegia were surgically managed at paraplegia hospital, New Civil Hospital, Ahmedabad, India during December 2004 to September 2006. Only those patients who had neurological status of grade A on ASIA impairment scale were included in the series. Thirty-six patients were male and four were female. Thirty-two patients had T12 fracture and eight patients had L1 fracture. Average age of patients was 42 years, and most of the patients were in their fourth decade. Age of patients ranged from 13 to 57 years. All patients had good bone quality. Associated injuries were found in 18 cases, of which 12 were fracture of calcaneum, which is explicable because the most common mode of 
injury in our patients was fall from height, being the reason for trauma in 32 cases. Eight patients were injured in roadtraffic accidents. Detailed history and examination carried out. After emergency treatment, plain radiograph in anteroposterior and lateral view were obtained. Mean angle of kyphosis was $34^{\circ}$. MRI was done to further evaluate important relationships and integrity of osseous and nonosseous tissue, instability of spine, and status of neural tissue. AO classification of thoracolumbar injuries was used to classify the fractures (Table 1). Twenty-two cases had incomplete burst fracture (type A3.1). Ten cases had burst-split fracture (A3.2). Next most common was complete flexion burst fracture (type A3.3.2), found in six cases. Two patients had complete axial burst fracture (type A3.3.3). Pros and cons of surgical treatment were explained to all patients. After understanding the nature of trauma and prognosis all patients underwent posterior transpedicular fixation. All patients were operated within 2 weeks. The average trauma-stabilization interval was 4 days, ranging from 1 to 12 days.

Technique of transpedicular fixation

The patient was placed prone on a four-poster frame to facilitate intraoperative imaging, maintain adequate sagittal alignment, and minimize any pressure to the anterior thorax or abdomen. After proper painting and draping, bony anatomy was exposed with standard posterior midline approach. Soft tissue was elevated from one level above to one level below the fracture using Cobb elevator so that anatomical landmarks could be clearly defined. Starting point was located at the junction of a vertical line along the lateral pars boundary and a transverse line dividing the transverse process in half. From starting points $2.5-\mathrm{mm} \mathrm{K}$ wires were inserted in all four pedicles under guidance of image intensifier. The image beam trajectory in the sagittal plane should be parallel to the superior vertebra end plate. In the transverse plane the image trajectory should be collinear to the pedicle insertion angle with the vertebral body. The spinous processes should be centered between the vertebral body boundaries to reduce any parallax effect. After confirming starting point in AP view and assessing screw path trajectory and depth in lateral view, pedicle tracts were formed with pedicle awl and all four tracts were palpated with depth gauge to measure size of screw as well as to verify presence of a bony floor and an intact four-wall boundary. Next the path was undertapped by $1.0 \mathrm{~mm}$ compared with the diameter of the selected screw. The pedicle screw was then inserted. Following screw insertion, intraoperative imaging was performed to verify acceptable screw positioning. Contoured rods were docked on either side and tightened after distraction kyphosis correction maneuver. Drain was placed and closure done in layers.
Table 1 Fracture types and management

\begin{tabular}{llll}
\hline $\begin{array}{l}\text { Fracture type } \\
\text { (AO-ASIF) }\end{array}$ & $\begin{array}{l}\text { No. of } \\
\text { cases }\end{array}$ & $\begin{array}{l}\text { Treated by } \\
\text { transpedicular } \\
\text { fixation only } \\
(n=20)\end{array}$ & $\begin{array}{l}\text { Staged anterior } \\
\text { decompression } \\
\text { and fusion } \\
(n=20)\end{array}$ \\
\hline Type A3.1 & 22 & 18 & 4 \\
Type A3.2 & 10 & 2 & 8 \\
Type A3.3.2 & 6 & 0 & 6 \\
Type A3.3.3 & 2 & 0 & 2 \\
\hline
\end{tabular}

Postoperative treatment and rehabilitation

Broad-spectrum intravenous antibiotic was given for 5 days. Drain was removed on second postoperative day and tilt-table mobilization was started with $25^{\circ}$ increment every day. Next, wheelchair activities were started. Stitches were removed on 12th postoperative day. With the support of posterior knee guards and toe-raising splints, patients were made to walk with walker as soon as they got power in hip. Orthosis was maintained for 4 months.

Second-stage anterior decompression and fusion was done in cases where:

1. Distraction kyphosis correction maneuver failed and there was more than $5^{\circ}$ kyphosis after posterior fixation (12 cases)

2. Any retropulsed fragment was seen on postoperative $\mathrm{X}$-ray (8 cases)

All patients in this group were operated within 3 weeks. Average trauma-decompression interval was 16 days, ranging from 6 to 21 days.

\section{Technique}

In anterior decompression, left 11th or 12th rib sided extra pleural-retroperitoneal approach in lateral position was used to expose the fractured vertebrae $[60,61]$. We did less invasive spinal surgery with the help of AO-ASIF synframe system and light source. During surgery AO-ASIF synframe provides stable operative field and direct visualization of the field with an incision of $6-8 \mathrm{~cm}$. Posterior two-thirds of vertebral body was excised and spinal canal was fully decompressed (Fig. 1). Reconstruction was carried out with mesh cage filled with bone graft obtained from resected vertebrae augmented with rib graft. Cage was placed anteriorly and centrally and clearly away from the canal (Fig. 2).

Drain was placed and closure done in layers. Patients were nursed supine and log-rolled for comfort. Chest drains were removed when $\mathrm{X}$-rays showed that the lung was expanded and drainage reduced. Postoperative treatment and rehabilitation protocol was the same as for stabilization 
group but rehabilitation was somewhat delayed because of pain and postoperative complications.

\section{Results}

Postoperative X-ray in all patients included in the study showed good hardware position (Fig. 3). Mean kyphosis correction was $22^{\circ}$ in all 40 cases. In 12 cases kyphosis was found to be more than $5^{\circ}$ after transpedicular fixation. Kyphosis $>5^{\circ}$ was considered as failure of kyphosis correction maneuver and staged anterior decompression was done. These cases were excluded from the first group and included in second-stage decompression group. Eight cases received anterior decompression because of retropulsed fragment that could not be reduced after transpedicular fixation. Mean lordosis in fixation group $(n=20)$ was $3^{\circ}$ postoperative and mean loss of correction was $6^{\circ}$ at 2 -year follow-up in this group. Fusion was achieved in all cases of decompression group and no loss of correction was observed in this group. Postoperative complications were significantly higher in staged decompression group and rehabilitation was delayed because of pain and postoperative complications (Table 2).

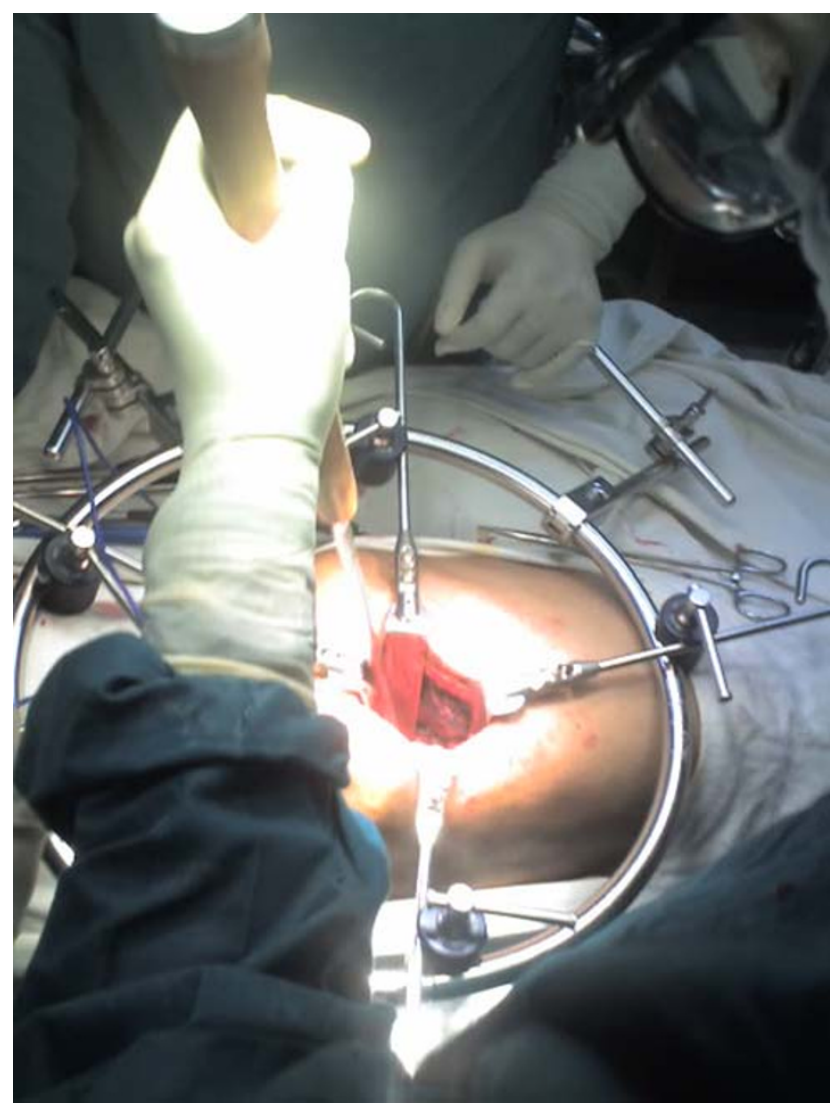

Fig. 1 Less invasive corpectomy and spinal canal decompression

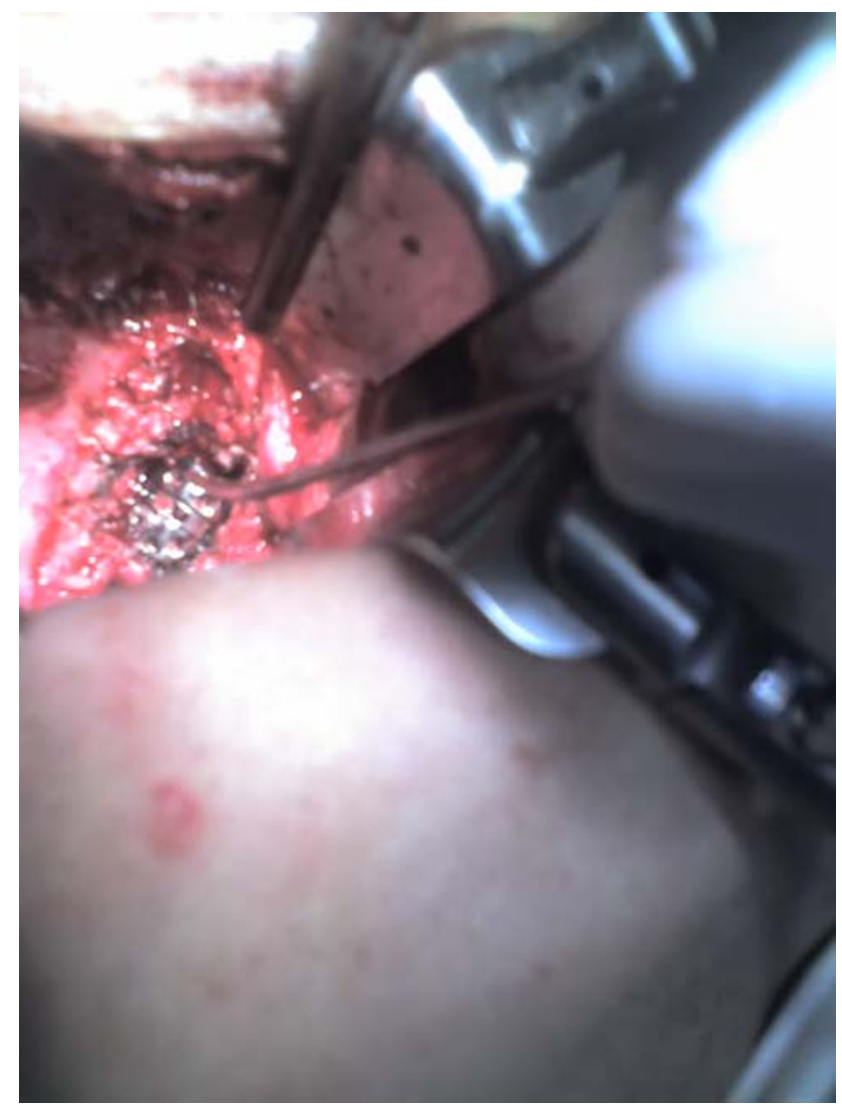

Fig. 2 Vertebral column reconstruction with mesh cage

Neurological improvement was better in staged decompression group, where the patients recovered by mean grade of 1.75 on American Spine Injury Association (ASIA) impairment scale. In fixation group patients recovered by mean ASIA grade of 1.3 (Table 3). No patient recovered completely.

Statistically, neurological recovery was better in decompression group. Analysis was done by making two groups according to recovery on ASIA impairment scale (Table 4). Application of chi-square test (Table 5) yielded $P=0.025$ and analysis of variance (ANOVA) (Table 6) yielded $P=0.033$, which is significant; interpretation is that neurological improvement by two or three grades of ASIA scale is better in the staged anterior decompression group than in the transpedicular fixation-only group.1

Although rehabilitation was faster in fixation-only group, at 2-year follow-up score on functional independence measurement scale (FIM) was considerably higher in staged decompression group (mean score 112) than in fixation-only group (mean score 98). Application of independent sample $t$-test resulted in $P<0.0001$, which shows that there was significantly higher functional recovery in the staged decompression group than in the fixation group (Tables 7, 8, 9). 


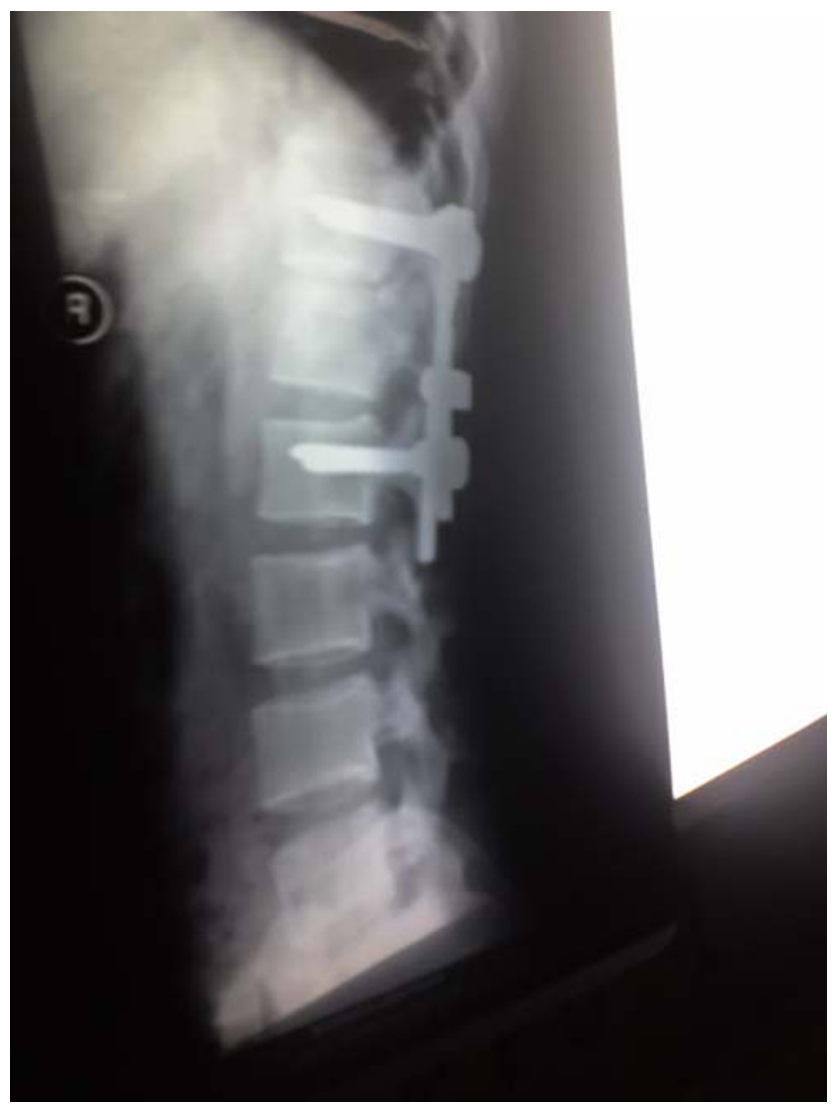

Fig. 3 Distraction kyphosis correction with pedicle screw system in burst fracture D12

Table 2 Postoperative complications

\begin{tabular}{llll}
\hline Complication & $\begin{array}{l}\text { No. of cases } \\
\text { in fixation } \\
\text { group }\end{array}$ & $\begin{array}{l}\text { No. of cases in } \\
\text { staged } \\
\text { decompression } \\
\text { group }\end{array}$ & $\begin{array}{l}\text { Total } \\
\text { no. of } \\
\text { cases }\end{array}$ \\
\hline Infection & 1 & 3 & 1 \\
$\begin{array}{l}\text { Bed sore } \\
\begin{array}{c}\text { Deep vein } \\
\text { thrombosis }\end{array}\end{array}$ & 1 & 3 & 7 \\
$\begin{array}{l}\text { Pneumonia } \\
\text { Urinary tract } \\
\text { infection }\end{array}$ & 0 & 1 & 1 \\
\hline
\end{tabular}

Out of 22 cases of type A3.1 fractures only four fractures required second-stage anterior decompression. These fractures were those where trauma-fixation interval was more than 7 days and distraction kyphosis correction maneuvers failed. Two patients in fixation group did not show any recovery. These two cases were of type 3.2. In decompression group two patients who recovered up to ASIA grade D were both of type 3.1 fractures and two who did not show any recovery were of type 3.3.3. No other significant correlation were observed between the fracture pattern and recovery.
Table 3 Neurological recovery at 2-year follow-up

\begin{tabular}{lcc}
\hline $\begin{array}{l}\text { Neurological recovery } \\
\text { on ASIA grading }\end{array}$ & $\begin{array}{l}\text { Fixation-only } \\
\text { group }\end{array}$ & $\begin{array}{l}\text { Staged } \\
\text { decompression } \\
\text { group }\end{array}$ \\
\hline No recovery & 2 & 2 \\
Recovery to ASIA grade B & 10 & 3 \\
Recovery to ASIA grade C & 8 & 13 \\
Recovery to ASIA grade D & 0 & 2 \\
Recovery to ASIA grade E & 0 & 0 \\
\hline
\end{tabular}

Table 4 Lower and higher recovery groups

\begin{tabular}{llll}
\hline Group & $\begin{array}{l}\text { Recovery by } \\
1 \text { grade or no } \\
\text { recovery }\end{array}$ & $\begin{array}{l}\text { Recovery by } \\
2 \text { or } 3 \\
\text { grade }\end{array}$ & Total \\
\hline $\begin{array}{l}\text { Fixation group } \\
\begin{array}{l}\text { Staged decompression } \\
\text { group }\end{array}\end{array}$ & 12 & 8 & 20 \\
Total & 5 & 15 & 20 \\
\hline
\end{tabular}

Table 5 Chi-square test

\begin{tabular}{|c|c|c|c|c|c|c|c|}
\hline & Value & $d f$ & $\begin{array}{l}\text { Asym } \\
\text { (two-s }\end{array}$ & $\begin{array}{l}\text { o. sig. } \\
\text { ided) }\end{array}$ & $\begin{array}{l}\text { Exact sig. } \\
\text { (two-sided) }\end{array}$ & $\begin{array}{l}\text { Exac } \\
\text { (one }\end{array}$ & $\begin{array}{l}\text { t sig. } \\
\text { sided) }\end{array}$ \\
\hline $\begin{array}{l}\text { Pearson } \\
\text { chi-square }\end{array}$ & 5.013 & 1 & 0.025 & & \multirow{6}{*}{0.054} & \multirow{6}{*}{\multicolumn{2}{|c|}{0.027}} \\
\hline $\begin{array}{l}\text { Continuity } \\
\text { correction }\end{array}$ & 3.683 & 1 & 0.055 & & & & \\
\hline $\begin{array}{l}\text { Likelihood } \\
\text { ratio }\end{array}$ & 5.134 & 1 & 0.023 & & & & \\
\hline $\begin{array}{l}\text { Fisher's } \\
\text { exact test }\end{array}$ & & & & & & & \\
\hline $\begin{array}{l}\text { Linear-by- } \\
\text { linear } \\
\text { association }\end{array}$ & 4.887 & 1 & \multirow{2}{*}{\multicolumn{2}{|c|}{0.027}} & & & \\
\hline $\begin{array}{l}N \text { of valid } \\
\text { cases }\end{array}$ & \multicolumn{2}{|l|}{40} & & & & & \\
\hline & \multicolumn{3}{|c|}{ Sum of squares } & $d f$ & Mean square & $F$ & Sig. \\
\hline Between groups & \multicolumn{2}{|c|}{2.025} & & 1 & 2.025 & \multirow[t]{3}{*}{4.886} & 0.033 \\
\hline Within groups & \multicolumn{2}{|c|}{15.750} & & 38 & \multirow[t]{2}{*}{0.414} & & \\
\hline Total & \multicolumn{2}{|c|}{17.775} & & 39 & & & \\
\hline
\end{tabular}

Summary of patients characteristics and comparison are tabulated in Table 10.

\section{Discussion}

Our study showed that outcome in patients of thoracolumbar junction burst fractures with complete paraplegia 
Table 7 FIM score

\begin{tabular}{lrrr}
\hline Intervention & Mean & $N$ & \multicolumn{1}{c}{ SD } \\
\hline Fixation group & 98.00 & 20 & 8.838 \\
Decompression group & 112.00 & 20 & 9.625 \\
Total & 105.00 & 40 & 11.551 \\
\hline
\end{tabular}

Table 8 FIM score group statistics

\begin{tabular}{lllrll}
\hline & Intervention & $N$ & Mean & SD & SEM \\
\hline FIM score & Fixation group & 20 & 98.00 & 8.838 & 1.976 \\
& Decompression group & 20 & 112.00 & 9.625 & 2.152 \\
\hline
\end{tabular}

depends on multiple factors such as fracture pattern, trauma-fixation interval, and type of surgery offered. The two groups in this study were not randomized, which is a weak point because more severe injuries underwent staged anterior decompression. In spite of severe injury pattern and morbidity of staged surgery the ultimate functional outcome (FIM score) was better in staged decompression group. In incomplete burst fractures transpedicular fixation and faster rehabilitation given comparable results in our series and is the only type of burst fracture which was treated satisfactorily with transpedicular fixation alone if done within 7 days. In our study only 4 cases out of 22 of type A3.1 fractures required anterior decompression and fusion because these were operated after 7 days, and distraction and kyphosis correction maneuvers failed in these cases. Only two cases of split burst fractures (type 3.2) were treated with transpedicular fixation alone and both did not show any recovery and had persistent back pain and recurrence of kyphotic deformity (loss of correction $>5^{\circ}$ ). It is important to take into consideration the results of Shono et al. [62], who have shown in their experimental study that posterior distractive reduction maneuver generates anterior and middle spinal column defects, leading to significant mechanical instabilities, particularly in axial compressive loading. Short-segment posterior pedicle screw fixation technique to resist axial spinal loading anteriorly is not adequate [63], but if the construct is used in neutral mode and adequate strut support is provided anteriorly, the efficacy and utility of pedicle screws is increased.

Anterior surgery achieves more complete and reliable decompression with interbody fusion along the lines of axial loading, which is very important in the biomechanics of the spinal functioning in this region. Anterior surgery has better canal clearance than posterior pedicle screws system. Edelker et al. [64] showed that two-motion-segment stabilization along with anterior bone grafting effectively addresses the anterior and middle columns.

Second-stage anterior decompression surgery is associated with higher complication rate and morbidity, even if done less invasively with AO-ASIF synframe system. The biggest problem is bed sores.

In spite of higher morbidity and postoperative complications the final results with staged anterior decompression are better than with transpedicular fixation alone.

Spinal canal decompression seems to be achieved indirectly by pedicular screw system, and it considerably reduced the immobilization and hospitalization time as it provide three-column biomechanical stability; however, with time it culminates in pain and deformity in cases of unstable burst fractures of thoracolumbar junction. Staged anterior corpectomy and mesh-cage implantation is a reliable surgical treatment in these patients. The advantages of this technique are complete kyphosis correction, immediate stability, preservation of kyphosis correction until fusion, and complete spinal canal decompression in case of neurological deficit. Anterior surgery along with posterior pedicle screw stabilization does give rigid stabilization and good clearance of the canal with satisfactory decompression of the spinal canal. It is proposed that surgical treatment providing a rigid spine capable of early bony arthrodesis should be advocated in cases of thoracolumbar burst fractures with complete paraplegia.

Table 9 Independent samples test

\begin{tabular}{|c|c|c|c|c|c|c|c|c|c|c|}
\hline & & \multicolumn{2}{|c|}{$\begin{array}{l}\text { Levene's test for } \\
\text { equality of } \\
\text { variances }\end{array}$} & \multicolumn{7}{|c|}{$t$ test for equality of means } \\
\hline & & \multirow[t]{2}{*}{$F$} & \multirow[t]{2}{*}{ Sig. } & \multirow[t]{2}{*}{$T$} & \multirow[t]{2}{*}{$d f$} & \multirow[t]{2}{*}{ Sig. (two-tailed) } & \multirow[t]{2}{*}{ Mean difference } & \multirow[t]{2}{*}{ SED } & \multicolumn{2}{|c|}{$\begin{array}{l}95 \% \text { Confidence } \\
\text { interval of the } \\
\text { difference }\end{array}$} \\
\hline & & & & & & & & & Lower & Upper \\
\hline \multirow[t]{2}{*}{ FIM score } & Equal variances assumed & 0.589 & 0.448 & -4.792 & 38 & 0.000 & -14.00 & 2.922 & -19.915 & -8.085 \\
\hline & Equal variances not assumed & & & -4.792 & 37.727 & 0.000 & -14.00 & 2.922 & -19.916 & -8.084 \\
\hline
\end{tabular}


Table 10 Comparison of characteristic in transpedicular fixationonly group $(n=20)$ and staged anterior decompression group $(n=20)$

\begin{tabular}{lll}
\hline Characteristic & $\begin{array}{l}\text { Fixation } \\
\text { group }\end{array}$ & $\begin{array}{l}\text { Staged } \\
\text { decompression group }\end{array}$ \\
\hline Mean age (years) & 41 & 42 \\
Sex (M/F) & $18 / 2$ & $18 / 2$ \\
Fracture level (T12/L1) & $16 / 4$ & $16 / 4$ \\
$\begin{array}{l}\text { Mean hospital stay (weeks) } \\
\text { Mean neurological recovery }\end{array}$ & 3 & 11 \\
$\quad$ (ASIA grade) & 1.75 & 1.3 \\
$\begin{array}{l}\text { Mean FIM score (functional } \\
\text { recovery) }\end{array}$ & 98 & 112 \\
$\begin{array}{l}\text { Postoperative complications } \\
\quad \text { no. of cases) }\end{array}$ & 4 & 12 \\
$\begin{array}{l}\text { Mean loss of kyphosis correction } \\
\text { Persistent pain at fracture site } \\
\quad(\text { no. of cases) }\end{array}$ & $6^{\circ}$ & 0 \\
\hline
\end{tabular}

Conflict of interest statement The authors have no conflict of interest. They do not have financial relationship with any organization. This study is not sponsored.

\section{References}

1. Mikles MR, Stchur RP, Graziano GP (2004) Posterior instrumentation for thoracolumbar fractures. J Am Acad Orthop Surg 12(6):424-435

2. Kirkpatrick AW, Mc Kevitt E (2002) Thoracolumbar spinal fractures, is there a problem? Can J Surg 45:21-24

3. Cotler JM, Vernace JV, Michalski JA (1986) The use of Harrington rods in thoracolumbar fractures. Orthop Clin North Am 17:87-103

4. Gertzbein SD, Court-Brown CM (1988) Flexion-distraction injuries of the lumbar spine: mechanism of injury and classification. Clin Orthop 227:52-60

5. Gumley G, Taylor TK, Ryan MD (1982) Distraction fractures of the lumbar spine. J Bone Joint Surg 64-B:520-525

6. Saboe LA, Reid DC, Davis LA, Warren SA, Grace MG (1991) Spine trauma and associated injuries. J Trauma 31:43-48

7. Weinstein JN, Collalto P, Lehmann R (1988) Thoracolumbar "burst" fractures treated conservatively: a long-term follow-up. Spine 13:33-38

8. Henderson RL, Reid DC, Saboe LA (1991) Multiple noncontiguous spine fractures. Spine 16:128-131

9. Ballock RT, Mackersie R, Abitbol JJ, Cervilla V, Resnick D, Garfin SR (1992) Can burst fractures be predicted from plain radiographs? J Bone Joint Surg 74-B:147-150

10. Brightman RP, Miller CA, Rea GL, Chakeres DW, Hunt WE (1992) Magnetic resonance imaging of trauma to the thoracic and lumbar spine. Spine 17:541-550

11. Petersilge CA, Patharia MN, Emery SE, Masaryk TJ (1995) Thoracolumbar burst fractures. Radiology 199:49-54

12. Fredrickson BE, Edwards WT, Rauschning W, Bayley J, Yuan H (1992) Vertebral burst fractures: an experimental, morphologic, and radiographic study. Spine 17:1012-1021
13. Frederickson E, Mann K, Yuan H, Lubicky J (1988) Reduction of the intracanal fragment in experimental burst fractures. Spine 13:267-271

14. Yamashita Y, Takahashi M, Matsuno Y et al (1990) Chronic injuries of the spinal cord: assessment with MR imaging. Radiology 175:849-854

15. Watson-Jones R (1931) Manipulative reduction of crush fractures of the spine. Br Med J 300

16. Denis F (1984) Spinal instability as defined by the three-column spine concept in acute spinal trauma. Clin Orthop Relat Res 189:65-76

17. Nagel DA, Koogle TA, Piziali RL, Perkash I (1981) Stability of the upper lumbar spine following progressive disruptions and the applications of individual internal and external disruptions and application of individual internal and external fixation devices. J Bone Joint Surg 63-A:62-70

18. McCormack T, Karaikovic E, Gaines RW (1994) The load sharing classification of spine fractures. Spine 19:1741-1744

19. Magerl F, Aebi M, Gertzbein SD, Harms J, Nazarian S (1994) A comprehensive classification of thoracic and lumbar spine injuriy. Eur Spine J 3:184-201

20. Denis F, Armstrong GW, Searls K, Matta L (1984) Acute thoracolumbar burst fractures in the absence of neurologic deficit. Clin Orthop Relat Res 189:142-149

21. Reid DC, Ho R, Dans LA et al (1988) The nonsurgical treatment burst fractures of the thoracolumbar junction. J Trauma 28:11881194

22. Canter JB, Lebwohl NH, Garvey T, Eismont FJ (1993) Nonoperative management of stable thoracolumbar burst fractures with early ambulation and bracing. Spine 181:971-976

23. Gertzbein SD (1992) Scoliosis Research Society multicenter spine fracture study. Spine 17:525-540

24. Weinstein JN, Collalto P, Lehmann TR (1988) Thoracolumbar "burst" fractures treated conservatively: a long-term follow-up. Spine 13:33-38

25. American Spinal Cord Injury Association (1992) Standards for neurological and functional classification of spinal cord injury, revised. American Spinal Cord Injury Association, Chicago

26. Bracken MB, Shepard MJ, Collins WF et al (1990) A randomised controlled trial of methylprednisone or naloxone in the treatment of acute spinal cord injury. N Eng J Med 322:1405-1411

27. Jacobs RR, Asher MA, Snider RK (1980) Thoracolumbar spinal injuries. Spine 5:463-477

28. Gertzbein SD (1992) Sclerosis Research Society: multicenter spine fracture study. Spine 17:528-540

29. Hashimoto T, Kaneda K, Abomi K (1988) Relationship between traumatic spinal canal stenosis and neurologic deficits in thoracolumbar burst fractures. Spine 13:1268-1272

30. Wood EG, Harley EW (1992) Thoracolumbar fractures: an overview with emphasis on the burst injury. Orthopedics 15:319323

31. Oldsworth FA, Hardy A (1952) Early treatment of paraplegia from fractures of the thoracolumbar spine. J Bone Joint Surg 35-B:540-550

32. Jickson H, Harrington PR, Erwin WD (1978) Results of reduction and stabilization of severely fractured thoracic and lumbar spine. J Bone Joint Surg 60-A:799-805

33. Frankel HL et al (1969) The value of postural reduction in the initial management of closed injuries of the spine with paraplegia and tetraplegia. Paraplegia 7:179-192

34. Burke DC, Murray DD (1976) The management of thoracic and thoraco-lumbar injuries of the spine with neurological involvement. J Bone Joint Surg 58-A:72-78

35. McAfee PC, Bohlman HH, Yuan HA (1985) Anterior decompression of traumatic thoracolumbar fractures with incomplete 
neurological deficit using a retroperitoneal approach. J Bone Joint Surg 67-A:89-104

36. Bradford DS, McBride CG (1987) Surgical management of thoracolumbar spine fractures with incomplete neurologic deficits. Clin Orthop 218:201-216

37. Benzel EC, Larson SJ (1986) Functional recovery after decompressive operation for thoracic and lumbar spine fractures. Neurosurgery 19:772-778

38. Bohlman HH (1980) Late anterior decompression and fusion for spinal cord injuries: review of 100 cases with long-term results. Orthop Trans 4:42-43

39. Bohlman HH, Stauffer ES, Ferguson R, Apple DF (1988) Paraplegia secondary to thoracolumbar spinal trauma. Contemp Orthop 16:57-86

40. Kaneda K, Abumi K, Fujiya M (1984) Burst fractures with neurologic deficits of the thoraco-lumbar spine. Results of anterior decompression and stabilization with anterior instrumentation. Spine 9:788-795

41. Maiman DJ, Larson SJ, Benzel EC (1984) Neurological improvement associated with late decompression of the thoracolumbar spinal cord. Neurosurgery 15:302-307

42. Chow GH, Nelson BJ, Gebbard JJ, Brugman JL, Brown CW, Donaldson DH (1996) Functional outcome of thoracolumbar burst fractures managed with hyperextension casting or bracing and early mobilization. Spine 21:2170-2175

43. Denis F, Armstrong GW, Searls K, Matta L (1984) Acute thoracolumbar burst fractures in the absence of neurologic deficit. Clin Orthop Relat Res 189:142-149

44. Mumford J, Weinstein JN, Spratt KF et al (1993) Thoracolumbar burst fractures: the clinical efficacy and outcome of nonoperative management. Spine 181:955-970

45. Canter JB, Lebwohl NH, Garvey T, Eismont FJ (1993) Nonoperative management of stable thoracolumbar burst fractures with early ambulation and bracing. Spine 181:971-976

46. Weinstein JN, Collalto P, Lehmann TR (1988) Thoracolumbar "burst" fractures treated conservatively: a long-term follow-up. Spine 13:33-38

47. Sasso RC, Renkens K, Hanson D, Reilly T, Mc Guire RA Jr, Best NM (2006) Unstable thoracolumbar burst fracture, anterior only versus short segment posterior fixation. J Spinal Disord Tech 19(4):242-248

48. Timothy R, Cresswell TR, Marshall PD, Smith RB (1988) Mechanical stability of the AO internal spinal fixation system compared with that of the Hartshill rectangle and sublaminar wiring in the management of the unstable burst fractures of the thoracic and lumbar spine. Spine 23:111-115

49. Yuan HA, Garfin SR, Dickman CA, Mardjetko SM (1994) A historical cohort study of pedicle screw fixation in thoracic, lumbar and sacral spinal fusions. Spine 19:2279S-2296S
50. Gestzbeni SD, Macmichael D, Tile M (1982) Harrington instrumentation as a method of fixation of fractures of the spine: a critical analysis of deficiencies. J Bone Joint Surg (Br) 64:526529

51. Dickman CA, Yahirs MA, Lu HTC, Melkerson MN (1994) Surgical treatment alternatives for fixation of unstable fractures of the thoracic and lumbar spine-a meta analysis. Spine 19; 20S:2279S-2296S

52. Temple HT, Kruse RW, van Dam BE (1994) Lumbar and lumbosacral fusion using Steffee instrumentation. Spine 19:537-541

53. Carl AC, Traumanhauser SG, Roger DJ (1992) Pedicle screw instrumentation for thoracolumbar burst fracture and fracture dislocations. Spine 17(suppl 8):S317-S324

54. Dickman CA, Yahiro MA, Lu HTC et al (1994) Surgical treatment alternatives for fixation of unstable fractures of thoracic and lumbar spine a metaanalysis. Spine 19(suppl 20):S2266-S2273

55. Knop C, Bastain L, Lange U, Blouth M (1999) Transpedicular fusion of thoracolumbar junction, clinical, radiographical and CT results. Orthopäde 28:703-713

56. Wood KB, Butterman G, Garvey T, Sichreist F, Jhanjee F, Mehbod A, Kane R (2000) Operative vs nonoperative treatment of thoracolumbar burst fractures without neurological deficit: a randomised prospective study. Scoliosis Research Meeting, Cairns Australia

57. Shen WJ, Liu TJ, Shen YS (2001) Nonoperative treatment versus posterior fixation for thoracolumbar junction burst fractures without neurologic deficit. Spine 26(9):1038-1045

58. Alanay A, Acaroglu E, Yazici M, Oznur A, Surat A (2001) Shortsegment pedicle instrumentation of thoracolumbar burst fractures: does transpedicular intracorporeal grafting prevent early failure? Spine 26(2):213-217

59. McLain RF, Sparling E, Benson DR (1993) Early failure of shortsegment pedicle instrumentation for thoracolumbar fractures. A preliminary report. J Bone Joint Surg Am 75(2):162-167

60. Kim M, Nolan P, Finkelstein JA (2003) Evaluation of 11th rib extrapleural-retroperitoneal approach to thoracolumbar junction. Technical note. J Neurosurg 93(1 suppl):168-174

61. Mc Cormick PC (1995) Retroperitoneal approach to the thoracic and thoracolumbar spine. Neurosurgery 37:908-914

62. Shono Y, McAfee PC, Cunningham BW (1994) Experimental study of thoracolumbar burst fractures-a radiographic and biomechanical analysis of anterior and posterior instrumentation systems. Spine 19:1711-1722

63. Yoganandan N, Larson SJ, Pintar F (1990) Biomechanics of lumber pedicle screw/plate fixation in trauma. Neurosurgery 27:873-880

64. Edelker DK, Asher MA, Neef JR et al (1991) Survivor analysis of VSP spine instrumentation in the treatment of thoraco lumbar and lumbar burst fractures. Spine 16:428-432 